\title{
Keterwakilan Politik Perempuan dalam Pemilu Legislatif Provinsi Riau Periode 2014-2019
}

\author{
Dessy Artina \\ Fakultas Hukum Universitas Riau \\ Kampus UR Gobah, Jalan Patimura No. 9 Pekanbaru \\ Echie_chay@yahoo.co.id
}

\begin{abstract}
Women and men have equal position in politics; women's participation is highly needed. Such thing is due to the fact that there are many issues regarding women's interests requiring women's representation in legislative institutions as well as regarding the 30\% quota for women in the election of legislative members in Riau Province in 2014-2019. This research focuses on the level of women's political representation in the legislative general election in Riau Province 2014 - 2019. This was a normative legal research. The data source was from primary and secondary law materials, and result of library research from various references. The finding shows that the level of women's representation increases as expected from the policy regarding women's representation.
\end{abstract}

Keywords: Political representation, women, legislative general election, Riau

\begin{abstract}
Abstrak
Perempuan dan laki- laki mempunyai kedudukan yang sama di politik, peran serta perempuan sangat diperlukan, hal ini dikarenakan banyaknya persoalan-persoalan terkait kepentingan perempuan yang perlu adanya keterwakilan perempuan di lembaga legislatif dan berpengaruh juga terhadap Kuota $30 \%$ Perempuan dalam Pemilihan Anggota Legislatif di Provinsi Riau periode 2014-2019. Penelitian ini fokus mengkaji tingkat keterwakilan politik perempuan dalam pemilu legislatif Provinsi Riau periode 20142019. Penelitian ini merupakan jenis penelitian hukum normatif. Data yang digunakan dalam penelitian ini bersumber dari bahan hukum primer, bahan hukum sekunder dan hasil library research dari berbagai referensi. Hasil penelitian menunjukkan tingkat keterwakilan perempuan meningkat, sesuai dengan harapan atas kebijakan yang ada tentang keterwakilan perempuan.
\end{abstract}

Kata kunci: Keterwakilan politik, perempuan, pemilu legislatif, Riau. 


\section{Pendahuluan}

Jaminan persamaan kedudukan laki-laki dan perempuan khususnya di bidang pemerintahan dan hukum telah ada sejak diundangkannya Undang-Undang Dasar 1945, 17 Agustus 1945, Pasal 27 ayat (1), menyebutkan bahwa: “Segala warga negara bersamaan kedudukannya di dalam hukum dan pemerintahan dan wajib menjunjung hukum dan pemerintahan itu dengan tidak ada kecualinya".

Negara yang menganut sistem demokrasi perwakilan, pertanggungjawaban pemerintah kepada rakyat disampaikan melalui lembaga perwakilan rakyat. ${ }^{1}$ Ketika parlemen Indonesia yang pertama dibentuk, perwakilan perempuan di lembaga itu bukan karena pilihan rakyat, tetapi pilihan dari pemuka-pemuka gerakan perjuangan, khususnya bagi mereka yang dianggap berjasa dalam pergerakan perjuangan mencapai kemerdekaan Indonesia. ${ }^{2}$

Demikian seterusnya, sampai pada zaman orde baru, ketika perempuan hanya diberikan status sebagai pendamping suami, organisasi perempuan terbesar waktu itu, yaitu PKK dan Dharma Wanita tidak memberi kontribusi dalam pengambilan keputusan politis, tetapi lebih menjadi alat pelaksanaan program pemerintah yang selalu cenderung "top down". ${ }^{3}$

Secara tegas hak perempuan untuk berpolitik dijamin dalam Konvensi tentang Penghapusan Segala Bentuk Diskriminasi terhadap Perempuan (Convention on the Elimination of All Forms of Discrimination against Women/CEDAW). Konvensi ini telah diratifikasi oleh Pemerintah Indonesia melalui Undang-Undang Nomor 7 Tahun 1984 tentang Pengesahan Konvensi mengenai Penghapusan Segala Bentuk Diskriminasi terhadap Wanita atau lebih dikenal dengan Konvensi Perempuan pada 24 Juli 1984. Sebelumnya Pemerintah Indonesia telah menandatangani konvensi tersebut pada 29 Juli 1980 saat mengikuti Konferensi Perempuan se-Dunia ke II di Kopenhagen.

Kewajiban negara yang terkait dengan hak politik perempuan juga terdapat dalam Rekomendasi Umum Komite CEDAW No. 23 (Sidang ke-16 Tahun 1997)

${ }^{1}$ Ramlan Surbakti, Memahami Ilmu Politik, Gramedia, Jakarta, 1999, hlm. 174.

${ }^{2}$ Riyan Sumindar, Kesiapan Publik, Perempuan dan Politik, makalah disampaikan pada seminar Kesiapan Publik Terhadap Pengarusutamaan Gender dalam Politik Pada Pemilu 2004, Bandung, 2004, hlm. 45.

${ }^{3}$ Ibid. 
tentang Perempuan dalam Kehidupan Publik. Komite ini memberikan rekomendasi bahwa negara peserta wajib: 1. menjamin dalam konstitusi dan peraturan perundang-undangan negaranya, prinsip-prinsip Konvensi yang berkaitan dengan Pasal 7 dan 8 Konvensi Perempuan; 2. menjamin bahwa partai politik dan serikat buruh tidak melakukan diskriminasi terhadap perempuan berkaitan dengan Pasal 7 dan 8 Konvensi Perempuan; 3. melakukan identifikasi dan melaksanakan tindakan khusus sementara untuk menjamin partisipasi yang setara antara perempuan dan laki-laki; 4. adanya kesempatan yang sama bagi perempuan dan laki-laki untuk menduduki jabatan publik yang didasarkan atas pemilihan (public elected positions) ${ }^{4}$

Penyelenggaraan pemilihan umum harus dilaksanakan secara lebih berkualitas dari waktu ke waktu agar tercipta derajat kompetisi yang sehat, partisipatif, dan mempunyai derajat keterwakilan yang lebih tinggi, serta memiliki mekanisme pertanggungjawaban yang jelas. Salah satu Undang-Undang yang mengatur pemilihan umum di Indonesia adalah Undang-Undang Nomor 10 Tahun 2008 tentang Penyelenggaraan Pemilihan Umum Anggota Dewan Perwakilan Rakyat, Dewan Perwakilan Daerah dan Dewan Perwakilan Rakyat Daerah. ${ }^{5}$

Undang-Undang Nomor 10 Tahun 2008 tentang Penyelenggaraan Pemilihan Umum Anggota Dewan Perwakilan Rakyat, Dewan Perwakilan Daerah dan Dewan Perwakilan Rakyat Daerah, memberikan peluang yang lebih besar bagi kaum perempuan untuk menempatkan kadernya di lembaga legislatif.Bagi partai politik yang minim kader perempuannya akan menimbulkan kesulitan dan berdampak tidak terisinya seluruh daerah pemilihan yang menawarkan kursi legislatif.

Selain itu, tanpa mengabaikan kelemahannya, Undang-Undang Nomor 10 Tahun 2008 tentang Penyelenggaraan Pemilihan Umum Anggota Dewan Perwakilan Rakyat, Dewan Perwakilan Daerah dan Dewan Perwakilan Rakyat

4 Achie Sudiarti Luhulima, "Hak Perempuan dalam Konstitusi Indonesia”, dalam Perempuan dan Hukum Meniju Hukum yang Berperspektif Kesetaraan dan Keadilan, Sulistiowati Irianto (ed), Yayasan Obor Indonesia, Jakarta, 2006, hlm. 92.

${ }_{5}$ Didik Supriyanto dan August Mellaz, "Ambang Batas Perwakilan Pengaruh Parliamentary Threshold Terhadap Penyederhanaan Sistem Kepartaian Dan Proposionalitas Hasil Pemilu”, at http://www.rumahpemilu.com/public/doc/2012_08_01_10_59_47_Ambang_Batas_Perwakilan_Didik_Supriya nto_dan_August_Mellaz.pdf, diakses 25 November 2013. 
Daerah lebih memberikan ruang kepada pemilih untuk memaksimalkan target pilihan, ketimbang kekuasaan pengurus partai politik, seperti sebelumnya. Para calon legislatif yang diajukan oleh partai politik yang mengusungnya harus lebih berkualitas, apalagi calon legislatif untuk lembaga legislatif daerah, harus betul-betul mengakar di daerah. Calon Legislatif untuk Dewan Perwakilan Rakyat Republik Indonesia akan terbantu oleh buah kerja keras calon legislatif di daerah. Hal ini dikarenakan penentuan peraihan kursi baru bisa dilakukan setelah menembus lebih dulu ambang batas parlemen atau angka 2,5\% suara sah secara nasional. ${ }^{6}$

Riau adalah sebuah provinsi di Indonesia yang terletak di bagian tengah pulau Sumatera. Provinsi ini terletak di bagian tengah pantai timur Pulau Sumatera, yaitu di sepanjang pesisir Selat Melaka. Hingga 2004, provinsi ini juga meliputi Kepulauan Riau, sekelompok besar pulau-pulau kecil (pulau-pulau utamanya antara lain Pulau Batam dan Pulau Bintan) yang terletak di sebelah timur Sumatera dan sebelah selatan Singapura..

Riau saat ini merupakan salah satu provinsi terkaya di Indonesia, dan sumber dayanya didominasi oleh sumber alam, terutama minyak bumi, gas alam, karet, kelapa sawit dan perkebunan serat. Tetapi, penebangan hutan yang merajalela telah mengurangi luas hutan secara signifikan,

Tidak dinafikan bahwa ada beberapa perempuan Riau yang ingin maju dalam segala bidang, maka penempatan posisi perempuan pada legislatif di Provinsi Riau menjadi sangat penting. Hal ini merupakan bagian dari kehidupan berdemokrasi dan transparansi dalam penyelenggaraan negara. Keterlibatan kaum perempuan di bidang politik, khususnya di legislatif akan memberikan keseimbangan dan mewarnai perumusan peraturan perundang-undangan, penganggaran dan pengawasan yang berspektif gender di Provinsi Riau.

Penduduk provinsi Riau terdiri dari bermacam-macam suku bangsa. Suku Melayu merupakan masyarakat terbesar dengan komposisi 37,74\% dari seluruh penduduk Riau. Mereka umumnya berasal dari daerah pesisir di Rokan Hilir, Dumai, Bengkalis, Kepulauan Meranti, hingga ke Pelalawan, Siak, Indragiri Hulu

\footnotetext{
${ }^{6}$ Didik Supriyanto dan August Mellaz, "Ambang Batas Perwakilan Pengaruh Parliamentary Threshold Terhadap Penyederhanaan Sistem Kepartaian Dan Proposionalitas Hasil Pemilu”, at http://www.rumahpemilu.com/public/doc/2012_08_01_10_59_47_Ambang_Batas_Perwakilan_Didik_Supriya nto_dan_August_Mellaz.pdf, diakses 25 November 2013.
} 
dan Indragiri Hilir. Suku bangsa lainnya yaitu Jawa (25,05\%), Minangkabau (11,26\%), Batak (7,31\%), Banjar (3,78\%), Tionghoa (3,72\%), dan Bugis $(2,27 \%)$. Ada juga masyarakat asli Riau bersuku rumpun Minangkabau terutama yang berasal dari daerah Rokan Hulu, Kampar, Kuantan Singingi, dan sebagian Inderagiri Hulu. Juga masyarakat Mandailing di Rokan Hulu, yang lebih mengaku sebagai Melayu daripada sebagai Minangkabau ataupun Batak.

Suku Melayu identik dengan Islam, sehingga penduduk asli Riau yang bersuku Melayu biasanya adalah penganut agama Islam. Budaya patriarki masih diwariskan secara turun temurun. Laki-laki lebih dominan dalam segala hal masih dirasakan dalam kehidupan sehari-hari, apalagi dalam hal kepemimpinan. Bahkan ada anggapan bagi sebagian orang di Provinsi Riau, bahwa perempuan tidak layak untuk menjadi pemimpin.

Provinsi Riau umumnya masih sulit menemukan perempuan yang benarbenar siap untuk masuk ke kancah politik yang memang berdasarkan keinginan sendiri, kemampuan, dan pengalaman sendiri. Ketidaksiapan tersebut bukan hanya karena faktor diri sendiri tetapi juga karena faktor eksternal, seperti budaya, agama, pemahaman dan perspektif masyarakat terhadap perempuan, oleh karena itu perlunya peran perempuan dalam parlemen supaya isu-isu terkait perempuan dapat diangkat disampaikan di parlemen.

\section{Rumusan Masalah}

Berdasarkan uraian tersebut di atas, maka permasalahan dalam penelitian ini adalah bagaimanakah tingkat keterwakilan politik perempuan dalam pemilu legislatif Provinsi Riau periode 2014-2019?

\section{Tujuan Penelitian}

Adapun tujuan yang hendak dicapai dalam penelitian ini adalah untuk menganalisis tingkat keterwakilan politik perempuan dalam pemilu legislatif Provinsi Riau periode 2014- 2019. 


\section{Metode Penelitian}

Penelitian ini menggunakan jenis penelitian hukum normatif karena peneliti melakukan penelitian dengan studi literatur dan peraturan perundang-undangan yang berhubungan dengan objek penelitian guna mencari jawaban atas masalah yang hendak diteliti. Sumber data yang digunakan dalam penelitian terdiri dari bahan hukum primer, bahan hukum sekunder dan melalui metode penelitian library research yang terdiri dari buku- buku, jurnal ilmiah, media masa dan internet serta referensi lainnya. Penelitian ini menggunakan teknik analisis deskriptif kualitatif, yaitu pengelompokan dan penyesuaian data-data yang diperoleh dari suatu gambaran sistematis yang didasarkankan pada teori dan pengertian hukum yang terdapat dalam ilmu hukum untuk menghasilkan kesimpulan yang signifikan dan ilmiah yang dapat menjawab rumusan masalah penelitian yang berhubungan tentang tingkat keterwakilan politik perempuan dalam pemilu legislatif Provinsi Riau periode 2014-2019.

\section{Hasil Penelitian dan Pembahasan}

\section{Jaminan Hak Politik Perempuan dalam Hukum}

Berbicara tentang hak politik perempuan, tidak ada satu aturan pun yang tidak mengakui hak memilih dan dipilih perempuan. Pada kenyataannya, perempuan lebih banyak menggunakan salah satu haknya, yaitu sebagai pemilih semata. Dalam hal ini partisipasi politik perempuan rendah. Sementara haknya untuk dipilih kurang diaplikasikan, sebab hukum tidak memberi dorongan untuk hal itu. Nilai-nilai yang timpang dalam masyarakat tentang hubungan gender telah terinternalisasi ke dalam diri perempuan dan diterima sebagai kebenaran oleh masyarakat luas. Tanpa bantuan hukum akan sulit mendorong perempuan untuk menggunakan haknya itu. Dengan kata lain, tidak adanya dukungan struktural akan membuat perempuan sulit melawan arus kultural yang melingkupi mereka. ${ }^{7}$

${ }^{7}$ Irma Latifah Sihite, Penerapan Affirmative Action Sebagai Upaya Peningkatan Keterwakilan Perempuan Dalam Parlemen Indonesia, Tesis UI, tidak dipublikasikan, 2011, hlm. 80. 
Sedikit mengingat bahwa prinsip dasar kehidupan kenegaraan yang demokratis adalah setiap warga negara berhak ikut aktif dalam proses politik. ${ }^{8}$ Disampaikan salah satu syarat dasar untuk terselenggaranya pemerintahan yang demokratis di bawah Rule of Law adalah perlindungan konstitusional, dalam arti bahwa konstitusi selain dari menjamin hak-hak individu, harus menentukan juga cara prosedural untuk memperoleh perlindungan atas hak-hak yang dijamin. ${ }^{9}$ Keadilan menuntut pentingnya distribusi yang sifatnya adil atas semua kesempatan, peranan, kedudukan, serta manfaat-manfaat atau nilai-nilai sosial asasi yang terdapat di dalam masyarakat. ${ }^{10}$ Terobosan atau kebijakan khusus perlu dipikirkan, untuk memungkinkan kaum perempuan berkesempatan meraih posisiposisi dalam panggung kemasyarakatan dan politik. Oleh karena itu, perlakuan khusus terhadap perempuan melalui UU Nomor 12 Tahun 2003 tentang Pemilihan Umum disambut hangat oleh berbagai kalangan, terutama aktivis perempuan. Dengan kebijakan ini diharapkan tingkat keterwakilan perempuan di parlemen meningkat. Mengingat mereka juga mewakili lebih dari setengah penduduk Indonesia. Penetapan kebijakan ini tampak kurang serius sebab tidak disertai dengan metode yang tepat, seperti zipper system,11 yang dapat menyelamatkan perempuan dari penempatan nomor urut bawah. Keresahan tersebut baru terjawab pada 2008 melalui Undang-Undang Nomor 10 Tahun 2008 tentang Pemilihan Umum. Zipper system ini akhirnya diadopsi, sehingga dalam tiga calon anggota legislatif harus ada satu perempuan. Adanya Putusan Mahkamah Konstitusi tentang suara terbanyak, maka target untuk mencapai 30\% akhirnya harus direlakan.

\section{Keterwakilan Perempuan dalam Politik dan Kuota 30\% Perempuan}

Masalah keterwakilan perempuan dalam politik di Indonesia menjadi wacana yang penting dalam upaya meningkatkan partisipasi politik perempuan.

8 Dahlan Thaib, Implementasi Sistem Ketatanegaraan Menurut UUD 1945, Liberty, Yogyakarta, 1993, hlm. 94.

${ }^{9}$ Muhammad Tahir Azhari, Negara Hukum Suatu Studi Tentang Prinsip-prinsipnya Dilihat dari Segi Hukum Islam, Implementasinya Pada Periode Negara Madinah dan Masa Kini, Bulan Bintang, Jakarta, 1992, hlm.45-49.

${ }^{10}$ John Rawls, A Theory of Justice, The President and Fellowship of Harvard University Press Cambridge, Massachusetts, New York, 1999, hlm. 95.

11 "ZipperSystem dan Eksistensi Peran Perempuan dalam Koncah Politik", http://google.co.id, diakses tanggal 8 Maret 2011. 
Pembicaraan mengenai keterwakilan politik perempuan tidak dapat dilepaskan dari partisipasi politik perempuan secara umum. Indonesia sudah meratifikasi dua konvensi yang berkaitan dengan partisipasi politik perempuan. Sebelum meratifikasi Konvensi CEDAW, Indonesia telah meratifikasi Konvensi tentang Hak-hak Politik Perempuan (The Convention on Political Rights of Women) pada 12 Desember 1958.

Dengan meratifikasi kedua konvensi tersebut, berarti Pemerintah Indonesia memiliki kewajiban untuk menjalankan setiap bagian dari pasal dari dua konvensi itu secara maksimal, terutama yang berkaitan dengan upaya untuk meningkatkan keterlibatan perempuan dalam politik, tetapi realitas politik yang ada saat ini menunjukkan bahwa tingkat partisipasi politik perempuan di Indonesia masih relatif rendah.

Realitas tersebut secara tidak langsung telah "merugikan" perempuan. Sesungguhnya keterwakilan politik perempuan sangat berani karena beberapa argumen. Pertama, dari segi demokrasi, jumlah perempuan lebih dari setengah jumlah total penduduk, yang merupakan bangunan teoretis yang wajar apabila wakil rakyat merefleksikan konstituennya. Kedua, dari segi kesetaraan, keterwakilan dari perempuan untuk perempuan, sama halnya dengan tuntutan atas keterwakilan dari rakyat untuk rakyat. Ketiga, dari segi penggunaan sumber daya, merupakan penggunaan kemampuan intelektual perempuan. Keempat, dari segi keterwakilan, banyak penelitian empiris yang menunjukkan bahwa bila perempuan tidak terlibat dalam pengambilan keputusan, maka kepentingan mereka tidak dipertimbangkan secara sungguh-sungguh.12

Banyak argumen yang menerangkan pentingnya keterlibatan dan keterwakilan perempuan dalam politik, tetapi kondisi empiris juga menunjukkan banyaknya faktor yang menghambat partisipasi politik perempuan. Center for AsiaPasific Women in Politics mencatat adanya dua faktor utama, yaitu: 1. pengaruh dari masih mengakarnya peran dan pembagian gender antara laki-laki dan perempuan yang tradisional yang membatasi atau menghambat partisipasi perempuan di bidang kepemimpinan dan pembuatan kebijakan atau keputusan; 2. kendala-

${ }^{12}$ Lihat pengantar buku Keterwakilan Perempuan di Lembaga-lembaga Nasional yang Anggotanya Dipilib melalui Pemilu: Perbedaan-perbedaan dalam Praktek. Internasional dan Faklor-faktoryang Mempengarubinya, IFES, tanpa tahun, hlm. i. 
kendala kelembagaan (institusional) yang masihkuat atas akses perempuan terhadap kekuasaan yang tersebar di berbagai kelembagaan sosial-politik, antara lain tipe sistem pemilihan umum (pemilu). ${ }^{13}$

Salah satu penelitian tentang keterwakilan perempuan di antaranya menunjukkan bahwa tiga faktor utama yang memiliki pengaruh paling signifikan terhadap tingkat keterwakilan perempuan dalam lembaga-lembaga yang anggotanya dipilih adalah: 1 . sistem pemilu; 2. peran dan organisasi partai-partai politik; 3. penerimaan kultural, termasuk aksi mendukung (affirmative action/aksi afirmatif atau diskriminasi positif) yang bersifat wajib atau sukarela. ${ }^{14}$

Salah satu bentuk affirmative action adalah pemberian kuota dalam jumlah tertentu bagi perempuan. Ide inti di balik sistem kuota adalah merekrut perempuan untuk masuk dalam posisi politik dan memastikan bahwa perempuan tidak sekedar merupakan sedikit "tanda" dalam kehidupan politik. ${ }^{15}$ Kuota bagi perempuan merupakan suatu jumlah tertentu atau persentase dari anggota suatu badan, apakah itu suatu daftar kandidat (calon anggota legislatif/caleg), majelis parlemen, suatu komite, atau suatu pemerintahan. Kebijakan ini bertujuan untuk memastikan agar perempuan, paling tidak, merupakan satu "minoritas kritis" (critical minority) yang terdiri dari 30\% atau 40\%. Satu hal yang penting adalah bahwa kuota ini hanya diterapkan sebagai tindakan temporer. Apabila hambatan struktural terhadap masuknya perempuan dalam politik telah dapat disingkirkan, maka kuota tidak perlu diterapkan lagi. Hal ini tidak tertepas dari dasar pertimbangan penerapan kuota itu sendiri, yaitu perempuan tertinggal jauh "start"-nya ketika memasuki dunia politik dibanding dengan laki-laki. Oleh karena itu, kuota tidak diperlukan lagi ketika keduanya sudah berada pada garis start yang sama.

Sebagian besar kuota menggunakan angka 30\%, karena angka 30\% diyakini sebagai "angka kritis" (critical number) yang harus dicapai untuk memungkinkan sebuah perubahan. Angka 30\% menunjukkan massa kritis (critical mass) yang akan memberikan dampak pada kualitas keputusan yang diambil dalam lembaga-

${ }^{13}$ Ibid, hlm. 21-30.

${ }^{14}$ IFES, Op. Cit., hlm. 7.

${ }^{15}$ Lihat Drude Dahlerup: "Menggunakan Kuota untuk Meningkatkan Representasi Politik Perempuan”, dalam Perempuan di Parlemen: Bukan Sekedar Jumlah, IDEA, 2002, hlm. 114. 
lembaga publik. Jumlah 30\% ditetapkan untuk menghindari dominasi dari salah satu jenis kelamin dalam lembaga-lembaga politik yang merumuskan kebijakan publik. ${ }^{16}$ Angka 30\% sebagai critical minority ini sesuai dengan Laporan Perkembangan PBB Tahun 1995 yang menganalisa gender dan pembangunan di 174 negara yang menyatakan bahwa:

Meskipun benar tidak ada hubungan nyata yang terbentuk antara tingkat partisipasi perempuan dalam lembaga-lembaga potitik dan kontribusi mereka terhadap kemajuan perempuan, 30\% keanggotaan dalam lembaga-lembaga politik dianggap sebagai jumlah kritis yang dapat membantu perempuan untuk memberikan pengaruh yang berarti dalam politik. ${ }^{17}$

Kuota sebenarnya bersifat gender neutral (netral gender), ${ }^{18}$ namun sebagian besar kuota yang diterapkan di dunia bertujuan untuk meningkatkan representasi perempuan, karena masalah yang biasanya muncul adalah kurang terwakilinya perempuan. Oleh karena itu, terdapat pendapat yang pro dan kontra mengenai ide kuota ini. Di satu pihak, kuota dianggap dapat memberikan kompensasi atas hambatan-hambatan aktual yang mencegah perempuan dari keterlibatannya secara adil. Di sisi lain, kuota dianggap diskriminatif, tidak demokratis, dan menentang prinsip kesempatan kesetaraan bagi semua. ${ }^{19}$

Terdapat berbagai argumen yang dikemukakan dalam mendukung atau menentang kuota. Alasan bagi mereka yang pro-kuota antara lain: 1. kuota bukanlah diskriminasi, tetapi kompensasi bagi kendala nyata yang dihadapi perempuan agar secara adil dapat berpartisipasi dalam kehidupan politik; 2. kuota berarti adanya sejumlah perempuan yang duduk bersama-sama dalam suatu komisi atau majelis, sehingga dapat mengurangi tekanan yang dirasakan oleh perempuan yang keberadaannya dalam suatu tempat sudah dialokasikan; 3. sebagai warga negara, perempuan memiliki hak perwakilan yang setara; 4. pengalaman perempuan berbeda dengan laki-laki; 5 . kualitas perempuan sama dengan laki-laki, tetapi kualitas perempuan dihargai lebih rendah dan dikecilkan

${ }^{16}$ M, B. Wijaksana, Modul Perempuan untuk Politik, Sebuab Panduan tentang Partisipasi Perempuan dalam Politik, Yayasan Jurnal Perempuan, Jakarta, 2004, hlm. 11.

${ }^{17}$ IFES, Op, Cit., hlm. 1.

18 Artinya kuota dapat juga diterapkan untuk laki-laki, misalnya untuk membantu laki-laki memasuki posisiposisi dimana wakil perempuan lebih mendominasi, seperti di sektor sosial. Lihat Dahlerup, Op. Cit., hlm. 86.

${ }_{19}$ Pro kontra ini secara lebih lengkap dapat dibaca dalam Dahlerup, Ibid., hlm. 115-116. 
(diminimalkan) dalam sistem politik yang dikuasai oleh laki-laki; 6. partai politiklah yang mengontrol pencalonan, bukan pemilih yang menentukan. ${ }^{20}$

Keberadaan perempuan dalam parlemen adalah penting sebab perempuan masih mengalami diskriminasi, baik itu diskriminasi kultural maupun struktural. Diskriminasi kultural tersebut bersumber dari tradisi masyarakat Indonesia yang bersifat patriarkis dan dari doktrin-doktrin agama. Diskriminasi struktural tersebut terlihat dalam peraturan perundang-undangan yang membakukan peran gender perempuan hanya sebatas di ranah domestik dan beberapa peraturan daerah yang tidak ramah terhadap perempuan dengan justifikasi agama. ${ }^{21}$

Perjuangan keterwakilan perempuan di Indonesia mulai di akomodir dalam Undang Undang Nomor 2 Tahun 2008 tentang Partai Politik. Undang-undang ini mencantumkan ketentuan tentang keterwakilan perempuan, yakni dalam hal pembentukan dan pendirian partai politik, serta kepengurusan partai politik di pusat dan daerah. Sebelumnya, keterwakilan perempuan bahkan telah diakomodir dalam Pasal 65 ayat (1) Undang-Undang Nomor 12 Tahun 2003 tentang Pemilihan Umum Anggota Dewan Perwakilan Rakyat, Dewan Perwakilan Daerah, dan Dewan Perwakilan Rakyat Daerah meskipun hanya dengan kalimat "dengan memperhatikan keterwakilan perempuan sekurang-kurangnya 30\%". Kebijakan ini menjadi harapan bagi perempuan Indonesia untuk berkiprah lebih jauh dalam ranah politik untuk memperjuangkan hak-hak perempuan khususnya dalam pembuatan kebijakan yang mendukung eksistensi perempuan sebagai bagian dari warga negara Indonesia.

Undang-Undang Nomor 2 Tahun 2008 tentang Partai Politik dan UndangUndang Nomor 10 Tahun 2008 tentang Pemilihan Umum Anggota Dewan Perwakilan Rakyat, Dewan Perwakilan Daerah, dan Dewan Perwakilan Rakyat Daerah bisa menjadi ukuran untuk melihat respon negara terhadap indikator kesetaraan gender, sebab Undang-Undang Nomor 10 Tahun 2008 tentang Pemilihan Umum Anggota Dewan Perwakilan Rakyat, Dewan Perwakilan Daerah,

${ }^{20}$ Dahlerup, Ibid., hlm. 88 dan MB. WWijaksana, Op. Cit., hlm. 11-12.

21 Penilaian terhadap suatu materi atau objek. Penilaian-penilaian ini berdasarkan suatu kriteria yang ditentukan sendiri atau menggunakan kriteria-kriteria yang ada, dalam hal ini agama. Lihat Yasinta Wintry, Hubungan Pengetahuan dan Sikap Ibu Hamil tentang Bayi Makrosomia di Klinik Bersalin Niar Jalan Balai Desa Kecamatan Medan Patumbak Tahun 2011, at http://repository.usu.ac.id/handle/123456789/27200, diunduh 7 April 2015. 
dan Dewan Perwakilan Rakyat Daerah dapat memberikan jaminan bagi perempuan untuk dapat mengikuti proses pencalonan sampai terpilihnya dalam pemilu. Hal ini bisa diketahui dari data yang disampaikan oleh Anggota KPU Pusat Ida Budhiati, bahwa jumlah keterwakilan perempuan di parlemen yang semakin membaik seiring dengan Undang-Undang Nomor 2 Tahun 2008 tentang Partai Politik dan Undang-Undang Nomor 10 Tahun 2008 tentang Pemilihan Umum Anggota Dewan Perwakilan Rakyat, Dewan Perwakilan Daerah, dan Dewan Perwakilan Rakyat Daerah yang terus direvisi. Peningkatan jumlah perempuan yang duduk di kursi legislatif hasil pemilu 2009, dibandingkan pemilu-pemilu sebelumnya. Pada 2004 jumlah anggota DPR perempuan hanya mencapai 11,8 persen dari 560 anggota DPR yang ada, lalu meningkat pada saat Pemilu 2009 dengan jumlah perempuan yang duduk di DPR mampu mencapai angka 18,05 persen. ${ }^{22}$ Tidak hanya di tingkat pusat, peningkatan keterwakilan perempuan di parlemen juga terjadi di daerah. Pada tahun 2004, keterwakilan perempuan di tingkat DPRD Provinsi dan DPRD Kabupaten/Kota jumlahnya hanya 10 persen. Jumlah tersebut kemudian meningkat 5 persen pada 2009 menjadi 15 persen.

\section{Analisis Putusan Mahkamah Konstitusi Nomor 22 - 24/PUU-VI/2008}

Putusan Mahkamah Konstitusi Nomor 22 - 24/PUU-VI/2008 tanggal 19 Desember 2008 antara lain berdampak terhadap Pasal 214 (huruf a s/d e) Undang Undang Nomor 10 Tahun 2008 tentang Pemilihan Umum Anggota DPR, DPD dan DPRD, yang tidak mempunyai kekuatan hukum. Ketentuan Pasal 214 dimaksud mengatur penetapan calon anggota legislatif terpilih (pada prinsipnya) berdasarkan nomor urut caleg sebagaimana ditetapkan Partai Politik pengusungnya. Sistem penetapan ini kemudian mengalami pergeseran akibat putusan Mahkamah Konstitusi, yaitu penetapan calon anggota legislatif terpilih berdasarkan jumlah perolehan suara masing-masing calon anggota legislatif.

Berdasarkan Putusan Mahkamah Konstitusi No. 22-24/PUU-VI/2008, maka penentuan calon anggota legislatif (Caleg) terpilih Pemilu 2009 harus didasarkan suara terbanyak secara berurutan; bukan atas dasar standar ganda, yaitu perolehan

${ }^{22}$ Keterwakilan Perempuan di Parlemen dan Kualitas Kebijakan", at http://beritapalu.com/catatanringan/2815-keterwakilan-perempuan-di-parlemen-dan-kualitas-kebijakan, diakses 12 Januari 2014. 
suara caleg dan nomor urut terkecil caleg yang ditetapkan partai politik (Parpol) bersangkutan sebagaimana indikasi oligarkhi partai selama ini. Substansi Pasal 214 Undang-Undang Nomor 10 Tahun 2008 tentang Pemilu Anggota DPR, DPD, dan DPRD merupakan acuan "redaksi" Pasal 55 ayat (2) bahwa "Di dalam daftar bakal calon sebagaimana dimaksud pada ayat (1), setiap 3 (tiga) orang bakal calon terdapat sekurang-kurangnya 1 (satu) orang perempuan bakal calon". Penetapan esensi norma Pasal 214 telah terjadi pada Undang-Undang Nomor 10 Tahun 2008 tentang Pemilu Anggota DPR, DPD, dan DPRD anggota legislatif (Pileg) sebelumnya, yaitu Undang-Undang Nomor 12 Tahun 2003 tentang Pemilihan Umum Anggota Dewan Perwakilan Rakyat, Dewan Perwakilan Daerah, Dan Dewan Perwakilan Rakyat Daerah tepatnya Pasal 107 ayat (2).

Penyusunan daftar bakal caleg sesuai Pasal 55 ayat (2) Undang-Undang Nomor 10 Tahun 2008 tentang Pemilu Anggota DPR, DPD, dan DPRD dikenal dengan sistem zipper. Ketentuan ini merupakan upaya affirmative action, yakni tindakan khusus sementara dalam rangka peningkatan kuantitas perempuan dalam lembaga legislatif guna merealisasikan prinsip negara hukum demokrasi. Esensi upaya tersebut didukung norma Pasal 53 bahwa "Daftar bakal calon sebagaimana dimaksud dalam Pasal 52 memuat paling sedikit 30\% (tiga puluh perseratus) keterwakilan perempuan".

Keputusan ini berdampak sistem penentuan caleg terpilih di Indonesia berubah dari berdasarkan nomor urut menjadi suara terbanyak, dengan kewenangan yang diberikan undang-undang kepadanya dapat secara langsung menetapkan calon terpilih berdasarkan putusan Mahkamah Konstitusi tersebut.

\section{Keterwakilan Perempuan dalam Pemilihan Legislatif di Provinsi Riau Periode 2014-2019.}

Undang-Undang Nomor 12 Tahun 2003 tentang Pemilihan Umum Anggota Dewan Perwakilan Rakyat, Dewan Perwakilan Daerah, dan Dewan Perwakilan Rakyat Daerah menentukan bahwa sistem pemilu 2004 adalah sistem proporsional terbuka. Pasal 65 ayat (1) Undang-Undang Nomor 12 Tahun 2003 tentang Pemilihan Umum Anggota Dewan Perwakilan Rakyat, Dewan Perwakilan Daerah, Dan Dewan Perwakilan Rakyat Daerah menyebutkan bahwa "Setiap partai politik 
peserta pemilu dapat mengajukan calon anggota DPR, DPRD Provinsi dan DPRD Kabupaten/kuota untuk setiap daerah pemilihannya dengan memperhatikan keterwakilan perempuan sekurang-kurangnya 30 persen“. Menurut hemat peneliti, pasal ini merupakan pasal setengah hati, pasal karet, bersifat sukarela karena tidak bersifat mengharuskan partai politik melaksanakan ketentuan tersebut dan tidak ada sanksi bagi partai politik yang tidak melaksanakannya. Hal ini membuka peluang bagi partai politik-partai politik yang selama ini didominasi laki-laki untuk mengabaikan aturan itu, dan pada akhirnya keterwakilan perempuan tetap tidak tercapai.

Dalam implementasi Undang-Undang Nomor 12 Tahun 2003 tentang Pemilihan Umum Anggota Dewan Perwakilan Rakyat, Dewan Perwakilan Daerah, dan Dewan Perwakilan Rakyat Daerah itu banyak tantangan dan kendala yang harus dihadapi perempuan legislatif (caleg). Setiap partai "harus" menyertakan perempuan caleg sedikitnya $30 \%$ perempuan dalam daftar calon anggota partainya atau non-partainya. Konsekuensi dari sistem pemilihan umum dengan sistem proporsional terbuka membawa konsekuensi yang cukup berat bagi perempuan yang meskipun $30 \%$ perempuan caleg dipenuhi, namun tentu perempuan (dan juga laki-laki) akan terpilih karena rakyat memilih langsung nama calon, bukan lagi partai. Tantangan pertama adalah dari sistem pemilu baru itu sendiri, yaitu dalam hal bilangan pembagi pemilih (BPP), yakni angka pendapatan suara disuatu wilayah dibagi kursi yang diperebutkan.

Persaingan perempuan caleg akan berat menghadapi sesama perempuan caleg dari partai lain dan dengan laki-laki caleg dalam memperebutkan sedikitnya kursi yang tersedia. Perubahan wilayah pemilihan dan penempatan calon jadi di partai adalah hal lain yang harus diperhatikan, karena tidak ada gunanya kalau perempuan calon legislatif berada di urutan bawah dalam daftar calon legislatif, sementara kursi yang diperebutkan di suatu daerah pemilihan hanya tiga. Misalnya perempuan caleg, terutama ditingkat kabupaten/kota harus mendekatkan diri langsung dengan masa pemilih. Kalau ditingkat provinsi dan pusat peran media masa cukup signifikan dalam membantu caleg memperkenalkan diri kepada masyarakat. Hal ini merupakan kendala dana kampanye yang cukup besar bagi caleg perempuan yang membiayainya sendiri. 
Sebelumnya caleg suatu partai diharuskan memberikan uang pendaftaran yang akan digunakan sebagai dana kampanye partainya, sejumlah tertentu yang tidak boleh melebihi jumlah yang di tentukan dalam Undang-Undang Nomor 10 Tahun 2008 tentang Pemilihan Umum Anggota Dewan Perwakilan Rakyat, Dewan Perwakilan Daerah, dan Dewan Perwakilan Rakyat Daerah yaitu Seratus Juta Rupiah. Jumlah tersebut bukan merupakan jumlah kecil.

Kompetisi di arena kampanye akan sangat keras antar perempuan sendiri mengingat hanya 30\%, lalu dengan caleg laki-laki dalam pemilihan terbuka yang mana para laki-laki tidak asing di dunia publik/ politik bagi masyarakat. Di sinilah kepiawaian perempuan caleg diuji, apalagi banyak daerah-daerah di Provinsi Riau budaya patriarkhinya sangat kuat dan daya penerimaan terhadap perempuan yang berkiprah di dunia publik sangat rendah.

Tantangan yang terberat bagi caleg perempuan datang dari sesama para perempuan itu sendiri. Tantangan lainnya adalah adanya beragam budaya yaitu tingkatan keterkungkungan mereka dalam budaya patriarkhi lokal, tingkat pendidikannya, tingkat pemahaman dan kesadaran akan pentingnya suara mereka terwakili dengan memadai, dan tingkat pandangan mengenai politik itu sendiri, tentang anggapan bahwa politik itu buruk dan kotor serta sudut pandang dari nilai- nilai agama. ${ }^{23}$ Pemahaman makna dari politik yang berperspektif perempuan harus di pahami terlebih dahulu, yang menjadi platform bagi dirinya sendiri dalam memperjuangkan perbaikan dan perubahan nasib perempuan di Provinsi Riau, sehingga bisa mengkritisi pandangan umum/maskulin bahwa politik adalah alat untuk memperoleh kekuasaan, daripada sebagai prasarana/sarana untuk memperbaiki keadaan Provinsi Riau. Partai politik adalah salah satu kendaraan arus utama (namun kendaraannya bukan milik pribadi, tetapi milik bersama anggota partainya/partai) yang berlaku di sistem pemilu, yang mau tak mau harus diikuti oleh para perempuan Provinsi Riau. Selain hal tersebut, seperti telah dikemukakan, perempuan Provinsi Riau telah tertinggal dalam aktivitas politik, tidak ada yang pernah menjadi pimpinan partai politik, padahal menurut aturan perundang-undangan salah satu persyaratan sebagai calon legislatif adalah

${ }^{23}$ Shafiyyah, Amatullah dan haryati Soeripno, Kiprah Politik Muslimah, Konsep dan Implementasinya, Gema Insani Press, Jakarta, 2003, hlm. 56. 
keaktifan calon legislatif. Kedudukan mereka dalam partai hanyalah menjadi anggota biasa, selalu tidak pernah menjadi orang yang diunggulkan. Kenyatannya perempuan cerdik cendikia atau perempuan teknokrat telah menjabat kedudukan tertentu di lembaga eksekutif dan yudikatif, seperti pegawai negeri sipil, hal yang tidak memungkinkan mereka masuk dalam lingkaran legislatif. Undang-undang telah menetapkan bahwa pegawai negeri sipil tidak boleh menjadi anggota partai politik. Hal ini tidak berarti bahwa tidak ada perempuan yang dapat memenuhi kualifikasi sebagai calon legislatif.

Pada pemilihan legislatif periode 2014-2019 di Provinsi Riau ada peningkatan kepercayaan masyarakat terhadap perempuan dalam politik. Jika dibandingkan pada periode sebelumnya, dan setelah adanya Putusan Mahkamah Konstitusi Nomor 22-24/PUU-VI/2008 terhadap Pasal 214 Undang-Undang Nomor 10 Tahun 2008 tentang Pemilihan Umum Anggota Dewan Perwakilan Rakyat, Dewan Perwakilan Daerah, dan Dewan Perwakilan Rakyat Daerah terhadap Kuota 30\% Perempuan, memberikan peluang yang begitu besar kepada perempuan dalam berpolitik. Jika melihat pemilu legislatif pada periode 2009-2014 dimana perempuan yang terpilih menjadi anggota badan legislatif berjumlah kaum perempuan hanya 10 (sepuluh) orang saja, merujuk kuota perwakilan perempuan, seyogyanya jumlah perempuan yang berkiprah di anggota DPRD Provinsi Riau ialah 18 orang, adapun nama-namanya anggota badan legislatif periode 2009-2014 adalah sebagai berikut; Almainis, S.Pd, Elly Suryani, SH, Dra. Hj. Iwa Sirwani Bibra, Supriyati, Lampita Pakpahan, Mukhtiarti Basko, T. Nazlah, Rosfalinda Zulher, Rita Zahara, dan Sumiyanti. Partisipasi perempuan dalam pemilu legislatif Provinsi Riau periode 2009-2014 masih sangatlah minim, jika dibandingkan periode pada periode 2014-2019 dimana adanya peningkatan terhadap jumlah perempuan yang terpilih menjadi anggota DPRD Provinsi Riau yang berjumlah 18 orang, Di antara 18 orang tersebut, Golkar merupakan partai terbanyak yang mengirimkan kader perempuannya di DPRD Riau, yang jumlahnya mencapai 7 orang (Nuraini, Karmila Sari, Sumiyanti, Sewitri, Septina Primawati, Sulastri dan Supriati) sementara Demokrat 3 orang (Eva Yuliana, Maghdalisni dan Yulianti), PDI Perjuangan 2 orang (Almainis dan Soniwati), PPP 2 orang (Yurnalis, Tengku Nazlah Khairati), Gerindra 1 orang (Lampita Pakpahan), PAN 1 orang (Ade Hartati 
Rahmat), PKS 1 orang (Mira Roza), NasDem 1 orang (Farida H Asad). Hal ini menunjukan bahwa implikasi dari putusan MK Nomor 22-24/PUU-VI/2008 memberikan semangat baru bagi para perempuan ikut serta dalam kanca politik di tanah air, tidak hanya kuantitas yang ada tetapi juga kualitas.

Peningkatan ini tentu berimplikasi pada pelaksanaan tugas-tugas mereka terutama dalam merencanakan dan sekaligus menghasilkan kebijakan-kebijakan yang sensitif gender. Sehubungan dengan itu perlu untuk dilacak bagaimana profil perempuan anggota DPRD di Provinsi Riau berdasarkan latar belakang pendidikan, jenis kelamin dan pengalaman berorganisasi, dan kedudukan dalam organisasi.

Sistem kuota sedikitnya 30\% perwakilan perempuan Indonesia dalam pengambilan keputusan diharapkan akan membawa perubahan pada: ${ }^{24}$ a. kualitas legislasi berperspektif perempuan dan gender yang adil; b. perubahan cara pandang dalam melihat dan menyelesaikan bebagai permasalahan politik dengan mengutamakan perdamaian dan cara-cara anti kekerasan; c. perubahan kebijakan dan peraturan undang-undang yang ikut memasukan kebutuhan kebutuhan perempuan sebagai bagian dari agenda nasional; dan $\mathrm{d}$. membuat perempuan berdaya untuk terlibat dalam berbagai permasalahan yang selama ini tidak mendapat perhatian di Indonesia, yang sensitif gender.

\section{Penutup}

Perempuan mempunyai peran dan kedudukan yang sama seperti laki-laki dalam politik. Peran serta perempuan sangat penting dalam dunia politik, karena banyak isu-isu terkait perempuan yang memerlukan adanya keterwakilan perempuan di lembaga legislatif. Pemilihan Anggota Legislatif di Provinsi Riau periode 2014-2019 berpengaruh terhadap kebijakan affirmative action keterwaklilan perempuan di legislatif Provinsi Riau. Pemilu Legislatif Provinsi Riau pada pemilu tahun 2014 mengalami peningkatan menjadi 18 orang, sedangkan pada pemilihan

${ }^{24}$ Imas Rosidawati, Keterwakilan Perempuan Di Dewan Perwakilan Rakyat Kesiapan Partai Politik \& Perempuan Indonesia Di Arena Politik Praktis, Ringkasan Penelitian, at http://www.uninus.ac.id/data/data_ilmiah/ Quota\%20Perempuan\%20di\%20DPR.pdf, diunduh 22 Juni 2013. 
umum sebelumnya yaitu pada periode 2009- 2014 berjumlah 10 orang. Dengan meningkatnya keterwakilan perempuan yang terpilih menjadi Anggota legislatif pada periode 2014-2019, diharapkan tidak hanya kuantitas yang diprioritaskan namun yang terpenting adalah kuantitas yang diikuti kualitas, sehingga perempuan berperan aktif dalam menjalankan tugas dan wewenangnya, seperti dalam menggunakan hak inisiatif untuk mengusulkan kebijakan-kebijakan atau peraturan-peraturan daerah berpihak untuk kepentingan perempuan.

\section{Daftar Pustaka}

Azhari, Muhammad Tahir, Negara Hukum Suatu Studi Tentang Prinsip-prinsipnya Dilihat dari Segi Hukum Islam, Implementasinya Pada Periode Negara Madinah dan Masa Kini, Bulan Bintang, Jakarta, 1992.

Dahlerup, Drude, "Menggunakan Kuota untuk Meningkatkan Representasi Politik Perempuan", dalam Perempuan di Parlemen: Bukan Sekedar Jumlah, IDEA, 2002.

Luhulima, Sudiarti, "Hak Perempuan dalam Konstitusi Indonesia", dalam Perempuan dan Hukum Мепuju Hukum yang Berperspektif Kesetaraan dan Keadilan, Sulistiowati Irianto (ed), Yayasan Obor Indonesia, Jakarta, 2006.

Rawls, John, A Theory of Justice, Massachusetts, New York: The President and Fellowship of Harvard University Press Cambridge, 1999.

Shafiyyah, Amatullah dan haryati Soeripno, Kiprah Politik Muslimah, Konsep dan Implementasinya, Gema Insani press, Jakarta, 2003.

Sihite, Irma Latifah, Penerapan Affirmative Action Sebagai Upaya Peningkatan Keterwakilan Perempuan, Tesis UI, tidak dipublikasikan, 2011.

Sumindar, Riyan, Kesiapan Publik, Perempuan dan Politik, makalah disampaikan pada seminar : Kesiapan Publik Terhadap Pengarusutamaan Gender dalam Politik Pada Pemilu 2004, Bandung, 2004.

Surbakti, Ramlan, Memahami Ilmu Politik, Gramedia, Jakarta, 1999.

Susiana, Sali, "Keterwakilan PerempuanDalam Undang-Undang Nomor 10 Tahun 2008 Tentang Pemilihan Umum Anggota DPR, DPD, DAN DPRD", Jurnal Kajian, Vol. 13, No. 3, September 2008.

Thaib, Dahlan, Implementasi Sistem Ketatanegaraan Menurut UUD 1945, Liberty, Yogyakarta, 1993.

Wijaksana, M, B. Modul Perempuan untuk Politik, Sebuah Panduan tentang Partisipasi Perempuan dalam Politik, Yayasan Jurnal Perempuan, Jakarta, 2004. 
Undang-Undang Dasar Negara Republik Indonesia Tahun 1945.

Putusan Mahkamah Konstitusi Nomor 22-24/PUU-VI/2008 Pengujian UndangUndang Nomor 10 Tahun 2008 tentang Pemilihan Umum Anggota Dewan Perwakilan Rakyat, Dewan Perwakilan Daerah, dan Dewan Perwakilan Rakyat Daerah.

Undang-Undang Nomor 12 Tahun 2003 tentang Pemilihan Umum Anggota Dewan Perwakilan Rakyat, Dewan Perwakilan Daerah, dan Dewan Perwakilan Rakyat Daerah(Lembaran Negara Republik Indonesia Tahun 2003 Nomor 37, Tambahan Lembaran Negara Republik Indonesia Nomor 4277).

Undang-Undang Nomor 2 Tahun 2008 tentang Partai Politik (Lembaran Negara Republik Indonesia Tahun 2008 Nomor 37, Tambahan Lembaran Negara Republik Indonesia Nomor 4277).

Undang-Undang Nomor 10 Tahun 2008 tentang Pemilihan Umum Anggota Dewan Perwakilan Rakyat, Dewan Perwakilan Daerah, dan Dewan Perwakilan Rakyat Daerah(Lembaran Negara Republik Indonesia Tahun 2008 Nomor 2, Tambahan Lembaran Negara Republik Indonesia Nomor 4801).

"ZipperSystem dan Eksistensi Peran Perempuan dalam Koncah Politik", http:/ / google.co.id, diakses tanggal 8 Maret 2011.

Keterwakilan Perempuan di Parlemen dan Kualitas Kebijakan", at http:/ / beritapalu.com/catatan-ringan/2815-keterwakilan-perempuan-diparlemen-dan-kualitas-kebijakan, diakses 12 Januari 2014.

Rosidawati, Imas, Keterwakilan Perempuan Di Dewan Perwakilan Rakyat Kesiapan Partai Politik \& Perempuan Indonesia Di Arena Politik Praktis, Ringkasan Penelitian, at http://www.uninus.ac.id/data/data_ilmiah/Quota\%20 Perempuan\%20di\%20DPR.pdf, diunduh 22 Juni 2013.

Supriyanto, Didik, dan August Mellaz, "Ambang Batas Perwakilan Pengaruh Parliamentary Threshold Terhadap Penyederhanaan Sistem Kepartaian Dan Proposionalitas Hasil Pemilu", at http://www.rumahpemilu.com/ public/doc/2012_08_01_10_59_47_Ambang_Batas_Perwakilan_Didik_Su priyanto_dan_August_Mellaz.pdf, diakses 25 November 2013

Wintry, Yasinta, Hubungan Pengetahuan dan Sikap Ibu Hamil tentang Bayi Makrosomia di Klinik Bersalin Niar Jalan Balai Desa Kecamatan Medan Patumbak Tahun 2011, at http://repository.usu.ac.id/handle/ 123456789/27200, diunduh 7 April 2015. 